\title{
DIGITALIZATION OF CORPORATE CULTURE AS A FACTOR INFLUENCING ESG INVESTMENT IN THE ENERGY SECTOR
}

\author{
ZAINULLIN Sergei ${ }^{1}$, ZAINULLINA Olga ${ }^{2}$ \\ ${ }^{1} R U D N$ University (RUSSIA) \\ ${ }^{2}$ University of Synergy(RUSSIA) \\ E-mail:zaynullin-sb@rudn.ru;
}

\begin{abstract}
The popularity of ESG (Environmental, Social and Governance) -investing is growing rapidly all over the world. More and more investors are moving from the traditional investment paradigm to investing based on the principles of environmental social corporate responsibility. One of the most affected by this trend is the energy industry. The report discusses the possibilities of applying methods of digitalization of corporate culture to increase the attractiveness of enterprises in the energy industry for ESG investment.

The study is based on the use of such methods of scientific knowledge as dialectical, a combination of historical and logical unity, structural analysis, traditional methods of economic analysis and synthesis, a review of both scientific sources describing ESG investment and the practical implementation of ESG approaches in the practice of corporations is carried out. The results are based on an analysis of current corporate policies and the implementation of ethical policies in corporate social reporting.

The article provides an overview of theoretical studies in relation to corporate non-financial reporting and the principles of responsible investment, provides statistical data on the attitude of investors towards ESG investment, analyzes the best practices of energy companies in digitalization, improving corporate culture to make them more attractive for ESG investment.
\end{abstract}

Keywords: ESG investment, corporate culture, digitalization, energy companies.

JEL:M14

DOI: $10.5937 /$ intrev2102132Z

UDC: 005.92:004.63]:620.9

005.73:005.35

COBISS.SR-ID 43519753 


\section{INTRODUCTION}

In 2018, the Danish pension fund RCA sold its stakes in 35 global oil and gas companies. According to the foundation, they did not fight climate change enough. The list of these companies names, in particular, three Russian companies (Lukoil, Rosneft, Gazprom), most of all (21) enterprises from the United States. [1]More and more investors around the world are beginning to pay attention not only to dividends and profits, but also to the social and environmental responsibility of business.

According to PwC, the volume of "responsible investing" has grown from \$23 trillion in 2016 to $\$ 31$ trillion in 2018. [2] In Europe, more than half of assets are managed by investors who pay attention to non-financial factors. According to EY, 97\% of institutional investors assess a company for its social responsibility. [3]

Interest in responsible investment is growing not only among institutional investors. According to a 2017 survey of 1,000 active private US investors conducted by Morgan Stanley Bank, 75\% of respondents are interested in such investments. [4]

In Russia, more and more companies, in addition to the usual financial ones, issue social reports (or reports on sustainable development). According to the Russian Union of Industrialists and Entrepreneurs, if in 200410 companies did this, then in 2018 - 175. In them, companies report on initiatives to improve corporate governance, corporate culture, ecology, and social responsibility. [5]

The active implementation of ESG approaches to investing requires a review and change of both individual corporate policies and the entire corporate culture. This is especially important for the energy industry, which creates a carbon footprint more than others and thus becomes less attractive for environmentally responsible investment. The prospect of introducing a carbon tax further reinforces the importance of introducing ESG practices into corporate culture. The novelty of the study is the study of approaches to the implementation of ESG in corporate social responsibility of the largest modern companies in the energy sector, in order to determine which corporations are already showing the best practices in ESG, and which are still lagging behind this trend.

\section{METODOLOGICAL FRAMEWORK}

ESG investing is founded and is part of the United Nations Principles for Responsible Investing. The six Principles for Responsible Investment are a voluntary and aspirational set of investment principles that offer a menu of possible actions for incorporating ESG issues into investment practice. In implementing them, signatories contribute to developing a more sustainable global financial system. Table 1.

Table 1.ESG Principles and their Implementing

\begin{tabular}{|c|c|c|}
\hline № & Principle & Possible actions \\
\hline Principle 1 & $\begin{array}{l}\text { We will incorporate } \\
\text { ESG issues into } \\
\text { investment analysis } \\
\text { and decision-making } \\
\text { processes. }\end{array}$ & $\begin{array}{l}\text { Address ESG issues in investment policy statements. } \\
\text { Support development of ESG-related tools, metrics, and analyses. } \\
\text { Assess the capabilities of internal investment managers to incorporate } \\
\text { ESG issues. } \\
\text { Assess the capabilities of external investment managers to incorporate } \\
\text { ESG issues. } \\
\text { Ask investment service providers (such as financial analysts, consultants, } \\
\text { brokers, research firms, or rating companies) to integrate ESG factors into } \\
\text { evolving research and analysis. } \\
\text { Encourage academic and other research on this theme. } \\
\text { Advocate ESG training for investment professionals. }\end{array}$ \\
\hline Principle 2 & $\begin{array}{l}\text { We will be active } \\
\text { owners and } \\
\text { incorporate ESG } \\
\text { issues into our } \\
\text { ownership policies } \\
\text { and practices. }\end{array}$ & $\begin{array}{l}\text { Develop and disclose an active ownership policy consistent with the Principles. } \\
\text { Exercise voting rights or monitor compliance with voting policy . } \\
\text { Develop an engagement capability. } \\
\text { Participate in the development of policy, regulation, and standard setting. } \\
\text { File shareholder resolutions consistent with long-term ESG considerations. } \\
\text { Engage with companies on ESG issues. } \\
\text { Participate in collaborative engagement initiatives. } \\
\text { Ask investment managers to undertake and report on ESG-related engagement. }\end{array}$ \\
\hline
\end{tabular}




\begin{tabular}{|c|c|c|}
\hline Principle 3 & $\begin{array}{l}\text { We will seek } \\
\text { appropriate } \\
\text { disclosure on ESG } \\
\text { issues by the entities } \\
\text { in which we invest. }\end{array}$ & $\begin{array}{l}\text { Ask for standardised reporting on ESG issues. } \\
\text { Ask for ESG issues to be integrated within annual financial reports. } \\
\text { Ask for information from companies regarding adoption of/adherence to } \\
\text { relevant norms, standards.. } \\
\text { Support shareholder initiatives and resolutions promoting ESG disclosure. }\end{array}$ \\
\hline Principle 4 & $\begin{array}{l}\text { We will promote } \\
\text { acceptance and } \\
\text { implementation of the } \\
\text { Principles within the } \\
\text { investment industry. }\end{array}$ & $\begin{array}{l}\text { Include Principles-related requirements in requests for proposals (RFPs). } \\
\text { Align investment mandates, monitoring procedures, performance } \\
\text { indicators and incentive structures accordingly. } \\
\text { Communicate ESG expectations to investment service providers. } \\
\text { Revisit relationships with service providers that fail to meet ESG } \\
\text { expectations. } \\
\text { Support the development of tools ESG integration. } \\
\text { Support regulatory or policy developments that enable implementation of } \\
\text { the Principles }\end{array}$ \\
\hline Principle 5 & $\begin{array}{l}\text { We will work } \\
\text { together to enhance } \\
\text { our effectiveness in } \\
\text { implementing the } \\
\text { Principles. }\end{array}$ & $\begin{array}{l}\text { Support/participate in networks and information platforms to share tools, } \\
\text { pool resources, and make use of investor reporting as a source of learning. } \\
\text { Collectively address relevant emerging issues. } \\
\text { Develop or support appropriate collaborative initiatives. }\end{array}$ \\
\hline Principle 6 & $\begin{array}{l}\text { We will each report } \\
\text { on our activities and } \\
\text { progress towards } \\
\text { implementing the } \\
\text { Principles. }\end{array}$ & $\begin{array}{l}\text { Disclose how ESG issues are integrated within investment practices. } \\
\text { Disclose active ownership activities. } \\
\text { Disclose what is required from service providers in relation to the } \\
\text { Principles. } \\
\text { Communicate with beneficiaries about ESG issues and the Principles. } \\
\text { Report on progress and/or achievements relating to the Principles using a } \\
\text { comply-or-explain approach. } \\
\text { Seek to determine the impact of the Principles. } \\
\text { Make use of reporting to raise awareness among a broader group of } \\
\text { stakeholders }\end{array}$ \\
\hline
\end{tabular}

Developed by the authors based on the UN Principles for Responsible Investment [6]

Researches of scientists ambiguously assess the world practice of using ESG investing. One of the key problems is the objectivity of assessments. Based on research conducted by Li, Polychronopoulos we have identified 70 different firms that provide some sort of ESG ratings data [7]. The authors also understand differently the reasons for the participation of investors in ESG financing. Two main groups of reasons that push investors towards ESG approaches: personal attitudes; regulations-oriented behaviors towards sustainability issues.

Brodback et al. provide survey evidence that there is a positive link between altruistic values and the relative importance of CSR and this effect is stronger when investors believe that they can make a positive social or environmental impact[8]. Brest et al.,observing that an increasing number of socially motivated investors have goals beyond maximizing profits, deepen the topic of social value [9]. Schramade [10]refers to UN's Sustainable Development Goals (SDGs) as an engine for a path to value creation, for society and shareholders.

Bialkowski and Starks [11]using a difference in difference approach, provide evidence that investor demand for socially responsible or sustainable and responsible funds results from investors' non-financial considerations. Bax et al.[12] define the need for an ESG approach to regulatory requirements. Regulatory authorities, such as the European Banking Authority (EBA), have acknowledged that ESG factors can contribute to risk.

Therefore, it is important to model such risks and quantify what part of a company's riskiness can be attributed to the ESG ratings. Nevertheless, the above authors, when discussing the reasons, the assessment criteria consider the ESG approach as an important factor that affects investment.

\section{RESULTS}

Digitalization methods in the corporate culture of energy companies are presented in corporate reporting. [13] The article provides a brief overview of the best practices for using digital tools. Électricité de France or EDF actively uses digital information in working with information systems for environmental monitoring, energy saving, procurement management, real estate. In particular, an Corporate Academy 
dedicated to new digital professions was created in 2019. EDF uses digital technology to improve information and support for the most vulnerable members of society.

The "EDF et moi" app (EDF \& I) provides all customers with a personalized space to help them understand and reduce their consumption in terms of euros or kWh. The "Equilibre" app is an interactive dashboard that allows customers to accurately track their energy consumption (electricity and natural gas) on their computer or tablet. They can display the energy consumed by each device and by type of use in euros or kWh: heating, hot water, household appliances, etc. Nearly 12 million customers have direct access to the Equilibre solution. Digital technologies are helping cities to use less energy. Municipalities gained access to digital tools to simulate future consumption or to remotely control equipment such as public lighting in real time.

A comprehensive automated database on the corporate ownership structure of the State Atomic Energy Corporation Rosatom was launched in order to optimize corporate governance processes and operational decision-making in all Russian subsidiaries. In order to ensure personnel continuity and prepare managers for appointment to managerial positions in the State Corporation Rosatom, since 2012, the centralized digital formation and development of the managerial personnel reserve has been carried out.

The total number of students who studied annually at universities commissioned by the State Corporation "Rosatom" in a targeted manner amounted to more than 2000 people. More than 6,000 students underwent practical training in the organizations of the Corporation. More and more students are being taught through the digital teaching method. In order to implement this policy, a Public Reporting Standard has been prepared, which is used by both the State Corporation and its organizations. Public reporting, including non-financial reporting, is disclosed on the digital platforms of Rosatom.

Confirmation of the effectiveness of Rosatom's methods for the implementation of ESG principles was the receipt of ESG loans in the amount of \$ 300 million in February-March 2021 at a low interest rate on the loan, provided that the borrower fulfills a number of obligations in the field of environmental protection during the construction of the Akkuyu NPP in Turkey [14].

Rosneft operates a unified corporate training system that covers all business areas and categories of personnel. A project was implemented to update the Model of Corporate and Management Competencies, taking into account the experience and best practices of foreign and Russian oil and gas companies. With the use of the new Competency Model, work has begun on evaluating candidates for the Company's talent pool. The Company is implementing a targeted innovative project "Implementation of a competency-based method for assessing and developing personnel in all segments of the Company's business"

China Petroleum \& Chemical., (Sinopec). The corporate vision is a long-term development plan that defines the growth goals and plans of the company. Sinopec implements development strategies of valuedriven, innovative, resource-optimized, open collaboration, green and low-carbon growth. Adjusting to the new business environment, Sinopec is accelerating its digital transformation and restructuring to improve product efficiency and quality to maintain its profitability and business competitiveness, and to introduce digital products to save energy.

PJSC Gazprom operates a system of continuous corporate professional education, which is based on the following principles: focus on the tasks of the Company, continuous education, an integrated and individual approach to employee training, and the effectiveness of the education received.

\section{DISCUSSION}

Principles for Responsible Investment is not a fundamentally new concept, Social reporting has already become widespread in corporate practice. According to a study of corporate social reporting by $\mathrm{KPMG}$, in contrast to annual financial reporting, social reporting does not have a mandatory form, but it has become widespread in the world thanks to The UN Global Compact, The Global Reporting Initiative - GRI ) [15]. Today, there are three main concepts on which modern theories of corporate social responsibility are based (Table 2). 
Table 2. Basic concepts of social responsibility of business.

\begin{tabular}{|l|l|l|}
\hline Concept name & $\begin{array}{l}\text { Authors and } \\
\text { followers }\end{array}$ & Content \\
\hline $\begin{array}{l}\text { Stakeholder group } \\
\text { concept }\end{array}$ & $\begin{array}{l}\text { Freeman R. E. } \\
\text { (1984). }\end{array}$ & $\begin{array}{l}\text { A stakeholder is a person or organization that is or is influenced by the } \\
\text { activities of another organization, its products, services and related } \\
\text { performance. }\end{array}$ \\
\hline $\begin{array}{l}\text { Corporate } \\
\text { citizenship } \\
\text { concept }\end{array}$ & $\begin{array}{l}\text { D.Matten, A. } \\
\text { Crane, W. } \\
\text { Chapple (2003]. }\end{array}$ & $\begin{array}{l}\text { Corporate citizenship implies the responsibility of companies for what } \\
\text { is happening in the country and the mutual responsibility of the state } \\
\text { and business to society }\end{array}$ \\
\hline $\begin{array}{l}\text { The concept of } \\
\text { corporate } \\
\text { sustainability }\end{array}$ & $\begin{array}{l}\text { Elkington J. } \\
\text { (1997) }\end{array}$ & $\begin{array}{l}\text { The concept of corporate sustainability based on the concept of a triple } \\
\text { bottom line of a corporation, including a financial and environmental } \\
\text { dimension, consistent with the idea of eco-efficiency, with the addition } \\
\text { of an assessment of social and broad economic impact }\end{array}$ \\
\hline
\end{tabular}

Developed by the authors based on the concepts [16][17] [18].

In Russia, large companies and companies with state participation are guided by an approach to social responsibility defined by the Concept of Long-Term Socio-Economic Development of the Russian Federation. [19]. The main direction of the transition to an innovative socially oriented type of economic development is the development of Russia's human potential. On the one hand, this presupposes the creation of favorable conditions for the development of the abilities of each person, improvement of the living conditions of Russian citizens and the quality of the social environment, on the other hand, an increase in the competitiveness of human capital and the social sectors of the economy that support it. On the issue of assessing the investment attractiveness, the opinion of the researchers was divided. Some scientists rely on the calculation of financial indicators Shcherbakova et) [20].

Another part note the need to take into account non-financial reporting, including factors containing ESG - environmental, social responsibility, corporate governance. According to Galazova [21], "the main trend in the inclusion of not only financial but also non-financial blocks in the corporate reporting of companies is the concept of sustainable development of the organization, designed to take into account the environmental, social and management factors that determine the company's activities.

According to Kabir [22] Socially responsible investment appeared in the business community as a result of the awareness of the impact of business on the environment and society, as well as the realization that this influence should be responsible According to Lavrentieva, Rudenko [23], the positive aspects of digitalization of organizational culture include the growth of personnel intellectualization, the possibility of remote personnel management, and increased labor productivity

Usov [24] believes that digitalization is the main trend in the development of corporate culture and from the point of view of digitalization, a mature company should have the following qualities:-Realize cross-functional tasks and projects (Collaborative).- Iterative, flexible approach (Agile). Risk- tolerant. Attracting talent and continuous learning. Flink (2021) [25] CEO of one of the largest funds - Black Rock, in an open appeal to corporate executives said Sustainability and Deeper Connections to Stakeholders Drives Better Returns. Over the course of 2020, we have seen how purposeful companies, with better environmental, social, and governance (ESG) profiles, have outperformed their peers. During 2020, 81\% of a globally-representative selection of sustainable indexes outperformed their parent benchmarks.

\section{CONCLUSION}

The authors conducted a study of the corporate culture of the world's largest corporations, including energy corporations, based on corporate non-financial reporting for 2016-2019. [26] Given the growing trend in the popularity of ESG investing, energy companies are modifying their corporate culture using more and more digital tools. When comparing the corporate culture of energy companies, the following conclusions can be drawn: Electricité de France, Rosatom State Corporation, Rosneft, Gazprom and Sinopec companies focus on training their employees using digital technologies and creating digital assessment and certification of personnel, personnel reserve systems, labor protection, which is determined by the high-tech nature of the energy industry.

Electricity de France, as its corporate social responsibility, focuses mainly on environmental issues (carbon reduction, alternative energy), energy efficiency and interaction with communities in places of 
operation, sustainable development goals, energy availability for consumers. Rosatom discloses in more detail information about its corporate culture - values, policies in the field of ethics, anti-corruption, discloses information on employee training, support for sports, culture, charity, educational programs for students and schoolchildren. She actively covers her activities in public and corporate media. Sinopec focuses on maintaining traditional values, collectivism, and company loyalty within the team. The participation of the company in the economic expansion of China within the framework of the "One Belt - One Road" program can also be attributed to the national specifics.

\section{ACKNOWLEDGMENT}

This paper has been supported by the RUDN University Strategic Academic Leadership Program

\section{REFERENCES}

[1] Economic Information Agency "Prime" The Danish Pension Fund has stopped investing in 35 oil companies, including those from the USA and the Russian Federation https://1prime.ru/energy/20180412/828710270.html

[2] Research of PWC ESG factors in investing. june 2019https://www.pwc.ru/ru/sustainability/assets/pwc-responsible-investment.pdf

[3] EY Research Nonfinancial disclosures are essential to most institutional investors Nov 2018 https://www.ey.com/en_gl/news/2018/11/nonfinancial-disclosures-are-essential-to-mostinstitutional-investors

[4] Research Morgan Stanley Millennials Drive Growth in Sustainable Investing August 2017https://www.morganstanley.com/ideas/sustainable-socially-responsible-investing-millennialsdrive-growth

[5] Research by the Russian Union of Industrialists and Entrepreneurs 2019.https://www.vedomosti.ru/economics/articles/2019/11/14/816278-nefinansovoi-otchetnosti

[6] United Nations Principles for Responsible Investment https:/www.unpri.org/pri/what-are-theprinciples-for-responsible-investment

[7] Feifei Li, Ari Polychronopoulos (2020) What a Difference an ESG Ratings Provider Makes! https://www.researchaffiliates.com/en_us/publications/articles/what-a-difference-an-esg-ratingsprovider-makes.html

[8] Brodback, D., Guenster, N., \& Mezger, D. (2018). Altruism and Egoism in Investment Decisions (June 4, 2018). http://dx.doi.org/10.2139/ssrn.2978660

[9] Brest, P. A. Gilson, R. J., \& Wolfson, M. A. (2018). How Investors Can (and Can't) Create Social Value. European Corporate Governance Institute (ECGI) - Law Working Paper No. 394/2018; Stanford University Graduate School of Business Research Paper No. 18-23

[10] Schramade, W. (2017). Investing in the UN Sustainable Development Goals (May 16, 2017). http://dx.doi.org/10.2139/ssrn.2968791

[11] Bialkowski, J., \& Starks, L. T. (2016). SRI Funds: Investor Demand, Exogenous Shocks and ESG Profiles. San Francisco, CA, USA

[12] Karoline Bax, Sahin Özg,Claudia Czado, Sandra Paterlini. ESG, Risk, and (tail) dependence. Preprint

[13] Corporate culture standards in the 21st century. Monograph. Zainullin S. B., Zainullina O. A. 2021 Publishing house: Direct-Media, Moscow | Berlin ISBN: 978-5-4499-1759-1 Pages: 433

[14] PJSC Sovcombank issued the next tranche of ESG-loan for the construction of Akkuyu NPP in Turkey https://sovcombank.ru/articles/novosti-kompanii/pao-sovkombank-vidal-sleduyuschiitransh-esg-kredita-na-sooruzhenie-aes-akkuyu-v-turtsii

[15] KPMG Survey of Corporate Responsibility Reporting. 2017.

[16] Freeman R. E. Strategic Management: A Stakeholder Approach. — First Edition. — Boston: Harpercollins College Div, January 1984. 
[17] Dirk Matten, Andrew Crane, Wendy Chapple, "Behind the Mask: Revealing the True Face of Corporate Citizenship", Journal of Business Ethics, Vol. 45, No. 1/2, 15th Annual Eben Conference: "Sustaining Humanity Beyond Humanism" (Jun., 2003).

[18] Elkington J. Cannibals With Forks: The Triple. Bottom Line of 21st Century Business. Capstone, Oxford, 1997.

[19] The concept of long-term socio-economic development of the Russian Federation, approved by the order of the Government of the Russian Federation dated November 17, 2008 No. 1662-r.

[20] Shcherbakova, N.S, Nazarova, Y.A., Navrotskaia, N.A., Bondarchuk, N.V., Vavilina, A.V. Evaluation of the gas industry company's competitiveness in the domestic market // International Journal of Energy Economics and Policy, 2020 - Vol. 10, Issue 5. - Pages 401-408. - DOI: 10.32479/ijeep. 9627.

[21] Galazova S.S. The impact of ESG factors on the sustainable development of companies and the financial performance of the corporate sector // Bulletin of the Rostov State University of Economics (RINH) 2018

[22] Kabir L.S. Responsible Investing: Trend or Temporary Phenomenon? // Economics. Taxes. Law, 2017

[23] Lavrentieva I.V., Rudenko D.S. Transformation of Organizational Culture in the Modern World // Bulletin of the Chelyabinsk State University. 2019

[24] A. Usov. Digitalization: people and culture are more important than technologies // 18 Oil of Russia 3-4 / 2018

[25] Larry Fink's 2021 letter to CEOs Read Larry Fink's 2021 letter to CEOs

[26] https:/www.blackrock.com/corporate/investitor-relations/larry-fink-ceo-letter

\section{Article history:}

Received 10 April 2021

Accepted 1 July 2021 